did not appear to alter the natural history of the disease in others, ${ }^{5}$ and their therapeutic value remains uncertain. Uncertainty about aetiology has limited therapy to symptomatic relief. It does seem clear, however, that oral contraceptives are contraindicated in women in whom established risk factors predispose them to develop primary pulmonary hypertension.

1 Thadani, U, et al, Quarterly fournal of Medicine, 1975, 173, 133.

2 Evans, W, Short, D S, and Bedford, D E, British Heart fournal, 1957, 19, 93.

${ }^{3}$ Shane, S J, et al, Canadian Medical Association fournal, 1964, 91, 145.

4 Wade, G, and Ball, J, Quarterly fournal of Medicine, 1957, 26, 83.

5 Walcott, G, Burchell, H B, and Brown, A L, Jr, American fournal of Medicine, 1970, 49, 70.

6 Wagenvoort, C A, and Wagenvoort, N, Circulation, 1970, 42, 1163.

7 Dresdale, D T, Schultz, M, and Michtom, R J, American fournal of Medicine, 1951, 11, 686

8 Goodwin, J F, Harrison, C V, and Wilcken, D E L, British Medical fournal, 1963, 1, 701.

9 Anderson, E G, Simon, G, and Reid, L, fournal of Pathology, 1973, 110, 273.

10 Follath, F, Burkart, F, and Schweizer, W, British Medical fournal, 1971, 1, 265.

11 Kleiger, R E, et al, Chest, 1976, 69, 143.

12 Oakley, C, and Somerville, J, Lancet, 1968, 1, 890.

${ }^{13}$ Bourdillon, P D V, and Oakley, C M, British Heart fournal, 1976, 38, 264.

\section{Dupuytren's contracture}

Since 1832 when Dupuytren ${ }^{1}$ became associated with this "mysterious disease" and laid down the principles of surgical management, it has been the subject of prolonged clinical debate and interest. Yet no real progress has been made in finding the cause of this thickening of the palmar fascia. Marc Iselin ${ }^{2}$ pointed out that the evolution of the disease was totally unpredictable (though the presence of knuckle pads is constantly associated with a poor prognosis) and wondered why an essentially benign lesion had the capacity to "invade" surrounding structures, making surgical excision all the more difficult.

Essentially Dupuytren's contracture is a European disease, and population studies ${ }^{3}{ }^{4}$ show that there is a $20-25 \%$ incidence in 65 -year-old men, rising to a $70 \%$ incidence in men of the same age with a family history-hence the genetic influence is strong. Other factors associated with it are epilepsy and chronic alcoholism, but trauma probably plays little part in its aetiology. ${ }^{5}$

When actual contracture occurs it may do so quite rapidly, and since the process is essentially painless the patient usually presents because the fingers are "getting in the way." From this stage the management of Dupuytren's contracture is largely surgical, though injecting triamcinolone into the palmar nodules will sometimes prevent contracture, and studies with enzyme fasciotomy are being evaluated. ${ }^{6}$

The successful surgical treatment of Dupuytren's contracture demands a full knowledge of the anatomy of the palmar fascia, ${ }^{7}$ and in particular the relation of the neurovascular bundles of the fingers to the digital bands of fascia. Dupuytren's surgical principles emphasised transverse skin crease incisions; division of the fascial bands responsible for the contracture; and the need to leave the wound open and to allow it to heal by granulation with the hand splinted in extension. All these principles have been subsequently challenged, save for the necessity to splint the hand in extension. Sir Archibald McIndoe emphasised the need for a radical excision of the palmar fascia, ${ }^{8}$ but postoperative com- plications and the sheer difficulty of radical excision of the fascia allowed the concept of limited palmar fasciectomy (excision of the diseased fascia) to gain acceptance. Howard ${ }^{9}$ reported percutaneous tenotomy of the contracted bands of fascia in older patients, while Gonzalez ${ }^{10}$ argued that Dupuytren's contracture in the finger should be treated like any other scar contracture, advocating transverse division of the bands and a full thickness skin graft to replace the defect in the skin caused by extension of the finger. Rodrigo et al ${ }^{11}$ compared the results of palmar fasciotomy and fascial excision and concluded that palmar fasciotomy had a definite place in the management of Dupuytren's contracture.

Patients should be chosen for surgical treatment on an individual basis, but in general it seems unwise to recommend operation for palmar nodules without contracture. The age of the patient and other factors such as alcoholism and "fleshy vasomotor hands" will also influence selection. Fasciotomy (with or without skin grafting) is best reserved for severely contracted bands in the palm or the fingers of old, debilitated patients, given that there will be a slowly progressive recurrence of the contracture. Probably other patjents are best treated by limited or partial fascial excision, the details of the technique chosen depending on the individual patient's contracture.

${ }^{1}$ Dupuytren, G, Leçons Orales de Clinique Chirurgicale, vol 1. Paris, Baillière, 1832.

2 Iselin, M, in Dupuytren's Disease, eds J T Hueston and R Tubiana, 3rd edn, p 67. Edinburgh, Churchill Livingstone, 1974.

${ }^{3}$ Ling, R S M, fournal of Bone and foint Surgery, 1963, 45B, 709.

4 James; J I P, in Dupuytren's Disease, eds J T Hueston and R Tubiana, 3rd edn, p 37. Edinburgh, Churchill Livingstone, 1974.

${ }^{5}$ Fisk, G, in Dupuytren's Disease, eds J T Hueston and R Tubiana, 3rd edn, p 45. Edinburgh, Churchill Livingstone, 1974.

${ }^{6}$ Hueston, J T, in Dupuytren's Disease, eds J T Hueston and R Tubiana, 3rd edn, p 141. Edinburgh, Churchill Livingstone, 1974.

7 Stack, H G, The Palmar Fascia. Edinburgh, Churchill Livingstone, 1973.

${ }^{8}$ McIndoe, Sir Archibald, and Beare, R L B, American fournal of Surgery, 1958, 95, 197.

${ }^{9}$ Howard, L D, Clinical Orthopaedics, 1959, 15, 118.

10 Gonzalez, R I, in Dupuytren's Disease, eds J T Hueston and R Tubiana, 3rd edn, p 123. Edinburgh, Churchill Livingstone, 1974.

${ }^{11}$ Rodrigo, J J, et al, fournal of Bone and foint Surgery, 1976, 58A, 380.

\section{How many antibiotics?}

How many antibiotics are there for treating bacterial infections? The tally should exclude griseofulvin and the polyenes, used only for fungal infections, and the whole range of synthetic antibacterials. Those accustomed to prescribe tetracycline or ampicillin for most purposes may be surprised to hear that Finland and his colleagues, ${ }^{1}$ restudying the susceptibility of haemolytic streptococci to antibiotics, thought it worth while to test 63 . Even so, their list left out quite a number in regular clinical use in some parts of the world. Of the 16 penicillins tested, most were familiar, but two were experimental products denoted only by numbers and two more were rarities in Britain-epicillin and cyclacillin. Flucloxacillin was missing, as was the Swedish azidocillin and the esters of ampicillin (talampicillin and two others) and of carbenicillin, since these have no antibacterial action as such. The original benzyl penicillin, with a median minimum inhibitory concentration of only $0.005 \mu \mathrm{g} / \mathrm{ml}$, remained the most active of all; we should be thankful that the susceptibility of these streptococci to penicillin has remained unchanged for over 30 years. Indeed, the main conclusion from this extensive 